\title{
44. The role of performance in constructing identity in the East and the West: comparison of the narratives of Köroğlu and the Knight with the Lion (Yvain)
}

\section{Zeynep ELBASAN BOZDOĞAN 1}

\begin{abstract}
APA: Elbasan Bozdoğan, Z. (2021). The role of performance in constructing identity in the East and the West: comparison of the narratives of Köroğlu and the Knight with the Lion (Yvain). RumeliDE Dil ve Edebiyat Araşttrmaları Dergisi, (23), 708-719. DOI: 10.2900o/rumelide.949659.
\end{abstract}

\begin{abstract}
Köroğlu, (lit. The son of the blind), is a 16th century folk hero who is believed to have lived in the city of Bolu, in north-west Anatolia. His epic adventures are widely known in the Eurasian region, mainly in Iran and Turkey, and his stories appear in the folk literatures of the many Caucasian countries such as Armenia, Georgia, Azerbaijan. We find a similar heroic style narrative in 12th century story of Yvain, The Knight with the Lion. Like Köroğlu, Yvain is also idealized as a symbol of social justice. The stories of Yvain and Köroğlu share many similarities in common. Seeking for avenge is the starting point of the stories. Although for different reasons, these two knights go on multiple journeys and the stories are constructed on the theme of chivalric adventure, separations, and reunions. This comparative study explores the concept of otherness which is integral to the comprehending of a person and the construction of gender as performance. The separation in both narratives indicate the meaning of "us" and "them". As another form of "othering", national character becomes fundamental and there is a performativity of identity in both narratives. While discussing the notion of otherness, one of the significant questions is to what extent the female characters were playing active roles in these narratives. Another point to be raised in this essay is the characterization of the heroes' animal companions. The relationship of the animals with their masters and their functions as "sauveur" is examined. The conclusion evaluates how the performative aspect of these two texts define the roles of the characters and construct identities.
\end{abstract}

Keywords: Köroğlu, Yvain, Middle Ages, legends, otherness, social justice

\section{Doğu ve Batı'da kimlik inşası sürecinde işlevselliğin rolü: Köroğlu ve Yvain hikayelerinin mukayesesi}

\section{$\ddot{\mathbf{O} z}$}

Köroğlu kuzeybatı Anadolu'nun Bolu şehrinde yaşadığına inanılan bir 16. yüzyıl halk kahramanıdır. Destansı maceraları başta İran ve Türkiye'de olmak üzere Avrasya bölgesinde yaygın olarak bilinmekte ve hikâyeleri Ermenistan, Gürcistan, Azerbaycan gibi birçok Kafkas ülkesinin halk edebiyatlarında yer almaktadır. Benzer bir kahramanlık tarzında anlatı 12. yüzyıldan Aslanlı Şövalye Yvain hikâyesinde görülmektedir.. Köroğlu gibi, Yvain de bir sosyal adalet sembolü olarak idealize edilmiştir. Yvain ve Köroğlu'nun hikâyelerinde birçok benzerlik söz konusudur. ortak nokta bulunur. İntikam arayışı hikâyelerinin çıkış noktasıdır. Her ne kadar farklı nedenlerle de olsa, bu iki şövalye birden fazla sefere çıar ve hikâyeleri macera, ayrılık ve yeniden bir araya gelme temaları üzerine inşa edilir. Bu mukayeseli çalışma kişinin performatif manada cinsiyet inşasını anlamak için “ötekileştirme” kavramını nasıl kullandığını sorgulamaktadır. Her iki anlatıdaki ayrımlar, "biz” ve

Dr. Arş. Gör., İndiana Üniversitesi, Merkezi Avrasya Çalıșmaları ve Karşılaştırmalı Edebiyat (Bloomington, İndiana, Amerika Birleşik Devletleri), zelbasan@indiana.edu, ORCID ID: 00oo-0001-5664-0515 [Araştırma makalesi, Makale kayıt tarihi: 05.03.2021-kabul tarihi: 20.04.2021; DOI: 10.2900o/rumelide.949659]

Adres | Address

RumeliDE Dil ve Edebiyat Araştırmaları Dergisi $\quad$ RumeliDE Journal of Language and Literature Studies Osmanağa Mahallesi, Mürver Çiçeği Sokak, No:14/8 Osmanağa Mahallesi, Mürver Çiçeği Sokak, No:14/8

Kadıköy - İSTANBUL / TÜRKIYE 34714 Kadıköy - ISTANBUL / TURKEY 34714 e-posta: editor@rumelide.com

e-mail: editor@rumelide.com,

tel: +90 505 7958124, +90 216773 o 616 phone: +90 505 7958124, +90 2167730616 


\begin{abstract}
"onlar" ın anlamını gösterir. Başka bir "ötekileştirme" biçimi olarak, millî bir karakterin her iki anlatıda da kimlik üzerinde nasıl odak noktası olduğunu görüyoruz. Ötekilik kavramını tartışırken önemli sorulardan biri de kadın karakterlerin bu anlatılarda ne ölçüde aktif rol oynadıklarıdır. Bu makalede vurgulanan diğer bir nokta ise kahramanların hayvan yoldaşlarının karakter olarak nasıl işlendiğidir. Hayvanların sahipleri ile ilişkileri ve bir takım zorluklarda "kurtarıcı" olarak üstlendikleri görevler de bu makalede ele alınmaktadır. Bu nedenle bu çalışmada her iki metnin de performatif yönünün karakterlerin rollerini nasıl tanımladığı ve ne tür kimlikler inşa ettiği değerlendirilmektedir.
\end{abstract}

Anahtar kelimeler: Köroğlu, Yvain, orta çă̆, epik, ötekileştirme, destan, sosyal adalet

\title{
Introduction
}

Köroğlu, lit. the son of the blind is a $16^{\text {th }}$ century folk hero who is believed to have lived in the city of Bolu, in north-west Anatolia. His epic adventures are widely known in the Eurasian region, mainly in Iran and Turkey, and his stories appear in the folk literatures of the many Caucasian countries, such as Armenia, Georgia, Azerbaijan. We find a similar heroic style narrative in the $12^{\text {th }}$ century story of Yvain, The Knight with the Lion. Like Köroğlu, Yvain is also idealized as a symbol of social justice. The stories of Yvain and Köroğlu share many similarities in common. For example, seeking for revenge is the starting point of the stories. Although for different reasons, these two knights go on multiple journeys and the stories are constructed on the theme of chivalric adventure, separations, and reunions.

The main subject of these narratives is to present the reasons for the emergence of a typical hero. In these narratives we encounter an ideal folk hero who defends the rights of the common people, who suffer from the injustices of a ruler. The hero, therefore, throughout his life acts as the defender of the folk. Throughout these journeys, as another layer of the narrative, there is discussion of the features of an ideal knighthood. It is obvious, at least so far as Chretien's version of Yvain and Anatolian versions of Köroğlu are concerned, that in the separation part of both stories is contained a careful rebuilding of Yvain and Köroğlu's moral characters and their reputations.

As a second stage, both narratives present the romantic adventures of Köroğlu and Yvain. There is a balance of romantic and heroic elements in these heroic poems. The romance presented in this group of stories involves courtly love, and the romance here has no mystic aspects. As long as they perform their duties, they are permitted to reach their lovers, so in this sense, their falling in love is very straightforward and natural. In addition, in these adventures, the horse and the lion appear as characters and play a significant role; however, their functions have attracted relatively little attention.

In order to address the issues suggested above, this comparative study will explore the concept of otherness, which is integral to the comprehending of a person and the construction of gender as performance. The separations in both narratives indicate the meanings of "us" and "them." As another form of "othering," the heroic character becomes fundamental, and there is a performativity of identity in both narratives, the role of which will be examined by comparing them. While discussing the notion of otherness, one of the significant questions will be to what extent the female characters were playing active roles in these narratives. Another point to be raised in this essay is the characterization of the heroes' animal companions. The relationship of the animals with their masters and their functions as

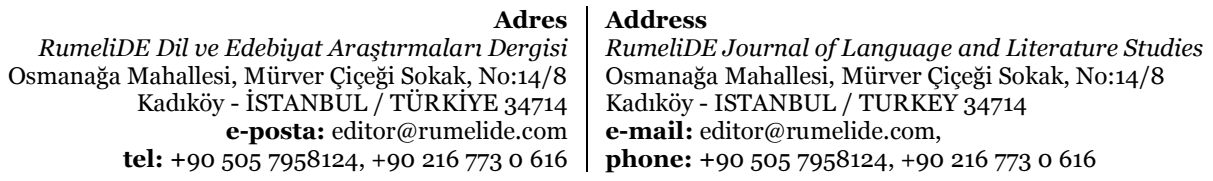


The role of performance in constructing identity in the East and the West: comparison of the narratives of Köroğlu and the Knight with the Lion (Yvain) / Z. Elbasan Bozdoğan (pp. 708-719)

"sauveur" will be examined. The conclusion will evaluate how the performative aspects of these two texts define the roles of the characters and construct their identities.

\section{Origins of Köroğlu}

The first mention of the name Köroğlu among Ottoman texts is found in Evliya Celebi's Seyahatname (The Book of Travels). According to the $17^{\text {th }}$ century Ottoman traveler Evliya Celebi, there are two figures of Köroğlu from 16th century; one is a social bandit fighting for justice, and the other is a troubadour in the Jannisary troops. Köroğlu's epic story-cycle provides an excellent example of epic story-cycles which cross linguistic and ethnic boundaries. There are four versions of this oral epic, which are available in Europe [Paris], Central Asia [Uzbekistan], Anatolia [Istanbul], and Siberia [Tobolsk]. Judith Wilks divides these versions in two groups, eastern and western, taking the Caspian Sea as the main delimiter between the two. What both groups have in common is their cultural or geographical attachment with the Persian Gulf region.

One of the questions about whether Köroğlu is a fictional character, or a real folk hero can be addressed by the official reports originating in the Ottoman Empire, which describe provincial disturbances caused by Köroğlu and his band as part of the Celali revolts. In these documents, Köroğlu's village and the region where he was active with his team as elusive bandits are elaborately explained. Eastern and western versions of Köroğlu narratives present our hero's profession differently. In the Azeri version of the narrative, Köroğlu's actions are those of an outlaw bandit who fights for social justice, whereas in other sources he is described as a poet. The story of Köroğlu begins with his father's loss of sight. We can summarize the story in four plots: The emergence of Köroğlu and his settlement in Çamlıbel, Köroğlu gathering brave men as a group of bandits, his heroic and sometimes romantic adventures with his men and his favorite companion Kirat, and finally disappearance or death of Kırat and Köroğlu. His name Köroğlu is given as a result of a tragic incident that takes place when he is a little boy. The feudal lord blinds his father for a trivial offense by plucking out his eyes. Father and son leave the town, taking with them their horse Kirat. This magically endowed horse was bred by a magician, who got the foal from a legendary seahorse and then raised the horse in a dark place. Father and son stop on the slope of the mountain Çamlıbel (lit. misty slopes; cf. Bakikhanov, pp. 181, 191), where they take a bath in the spring. The spring's magic water endows Köroğlu with the gift of poetry so that he becomes a minstrel. To take revenge for the mistreatment that his father had to face, he gathers a group of men who are active in Celali revolts. Therefore, Köroğlu himself also plays a role as a fighter for justice in these revolts.

Köroğlu can be identified as a folk hero, and his stories are widely spread in the lands where Turks lived. Different versions of the narratives were shaped according to the events that Köroğlu went through, and his character was depicted differently in various regions in which his story was being told. One of the challenges in studying Köroğlu is that the narrative had a wide audience, and as an epic story it reflected locally important historical, social and cultural events, which resulted in changes depending on the region. His name first appears in the account of Armenian historian Arakel from Tabriz, today's Iran. He mentions Köroğlu's name while giving a list of people who were involved in the Celali Revolts, which took place between the $16^{\text {th }}$ and $17^{\text {th }}$ centuries. Arakel describes him briefly, saying: "Bards play saz² and narrate Köroğlu's adventures in cycles."3 (İçel, 2010: 5) This account is taken as a fundamental source for some researchers who believe that Köroğlu himself was a Celali.

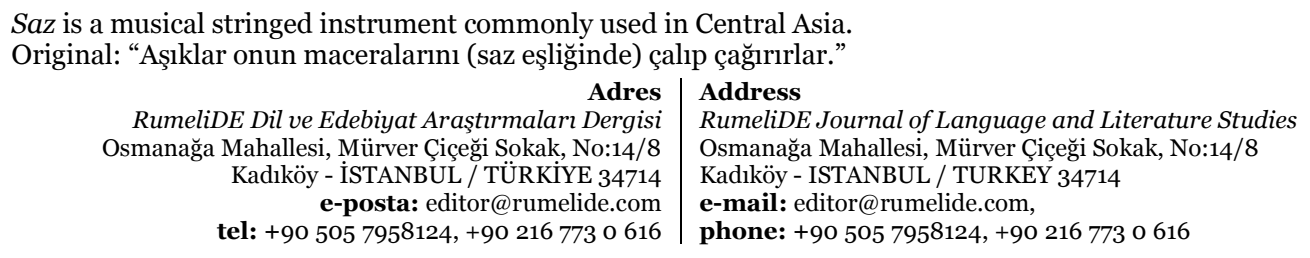


Another Ottoman source from the $17^{\text {th }}$ century is the travel narrative of Evliya Çelebi (1611-1682), who mentions Köroğlu's name on his way from İstanbul to Van, a city in the eastern region of Anatolia. When Çelebi and his companions break their journey at a hostel in the city of Bolu, seven bandits stop them for burglary. Çelebi's response to the bandits is as follows: "Even Köroğlu did not do such a thing that you did to us." 4 This statement can also be given as evidence of Köroğlu being a Celali rebel. Samuelyan also traces Köroğlu back to the $17^{\text {th }}$ century in the Armenian version of the story. (İçel, 2010: 6) The most extreme statement comes from Şopen, who states that Köroğlu lived in the war time of Arabs and Armenians at some time between the $7^{\text {th }}$ and $10^{\text {th }}$ centuries. Leading Turkish historians Ziya Gökalp and Zeki Velidi Togan insist that Köroğlu was a prototype for Sultan Mahmud of Ghazna, so he was a noble knight, and these historians trace Köroğlu's epic to the $11^{\text {th }}$ century. The popular conviction in Turkish and Azeri versions, which this study will focus on, is that Köroğlu was a Turcoman from nomadic Teke clans, and his father was under the service of Sultan Mahmud IV (r.1623-1640).

Although the stories of Köroğlu appear in various sources of the region from which Köroğlu emerged, the first complete series of Köroğlu stories were compiled by a Russian diplomat and Iranologist Alexander Chodzko in the $19^{\text {th }}$ century, who translated the stories from the Perso-Turkish dialect into English. The name "Köroğlu" appears differently in every region. In the Caucasian version, it appears as "Karaoğlu", while in Chodzko's text,it appears as "Kurroglou." Chodzko says that Köroğlu, a native of Northern Khorasan, is an illiterate nomad who lived in the second half of the $17^{\text {th }}$ century. (Chodźko, 1842: 3) He describes Köroğlu as "a model warrior, their national model bard, in all the significance of those terms. The ideal of Kurroglou is the fidelity of a warrior to his knightly word, and, above all, a wild, unbounded freedom." (Chodźko, 1842: 7) Chodzko states that as the work of a European traveler, the beauty of Köroğlu's poems was the reason for compiling his book. Chodzko traces Köroğlu's poems back to the $1^{\text {th }}$ century Iranian poet Ferdowsi stating that Köroğlu also avoided using even one single Arabic word. This statement can be misleading, because there is no evidence of Köroğlu supporting the use of a pure Persian language, avoiding all foreign elements. In fact, most of the Köroğlu poems were in Turkish. As another difference, while as a writer Ferdowsi adopted the old national tradition of narrating events using super-natural world elements, he also included major events from Persian history. Moreover, while in the case of Shahnama, the intended audience was the court of Ghaznavid, and Ferdowsi's ultimate goal was to be under the patronage of the Sultan Mahmud of Ghazni, Köroğlu's improvisations arose naturally, narrating such events as merely human, and Köroğlu had no intention of gaining the favor of a patron. The only similarity between Köroğlu's poems and Ferdowsi's book of chronicles Shahnama, Book of Kings, is that they were both very popular throughout those lands and widely recited.

The stories of Köroğlu can be grouped as full texts and pieces. Boratav groups the uncompleted oral versions into six groups, and four of these, the versions of Urfa, Yalvaç, Elaziz and Maraş, were collected from Anatolia region.

\footnotetext{
4 Bu sizin yaptığınızı bu dağlarda Köroğlu yapmamıştır!” (Çevik, 1984: 7)

Adres $\mid$ Address

RumeliDE Dil ve Edebiyat Araştrmaları Dergisi $\quad$ RumeliDE Journal of Language and Literature Studies Osmanağa Mahallesi, Mürver Çiçeği Sokak, No:14/8 Osmanağa Mahallesi, Mürver Çiçeği Sokak, No:14/8 Kadıköy - İSTANBUL / TÜRKIYE 34714 Kadıköy - ISTANBUL / TURKEY 34714 e-posta: editor@rumelide.com e-mail: editor@rumelide.com tel: +90 $5057958124,+90216773$ o 616 phone: +90 505 7958124, +90 216773 o 616
} 
The role of performance in constructing identity in the East and the West: comparison of the narratives of Köroğlu and the Knight with the Lion (Yvain) / Z. Elbasan Bozdoğan (pp. 708-719)

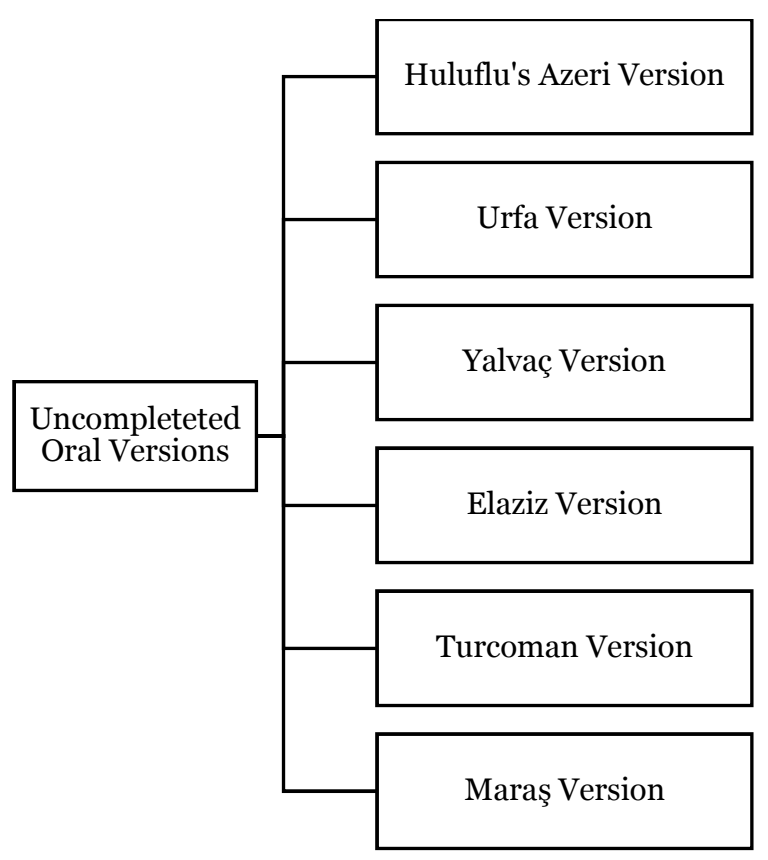

Full written texts are identified in four categories:

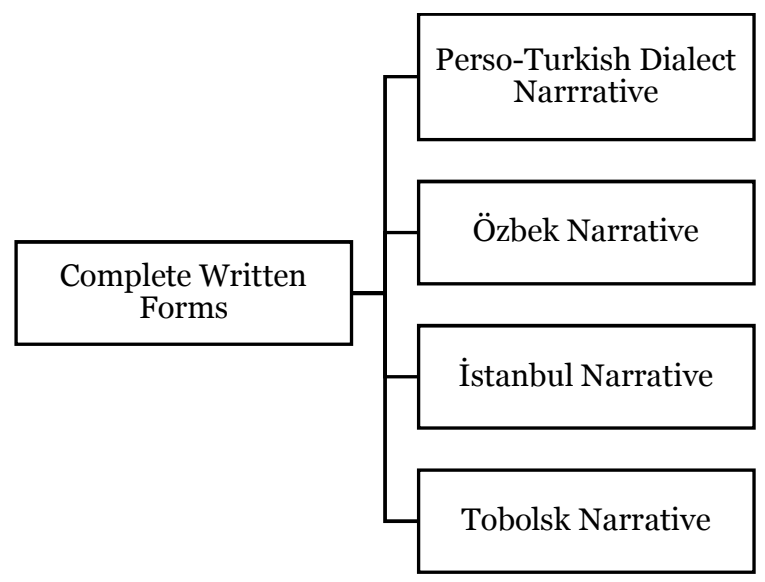

It is a natural process for historical events to be reflected in narratives and for scholars to interpret them in their regional contexts. Axel Olrik in his book, Principles for Oral Narrative Research, says that "the secondary task of oral narrative research is to use the narrative as evidence of external conditions, such as social structure, worship, and political events." (Olrik, 1992: 1) For this reason, in the versions of Central Asia, readers find reports of Safavid Turcoman wars and resistance to the Arab invasions in the region, while in the western versions, we see the footprints of Celali and Tebrizi revolts. Different historical events change the profiles of the characters and even the structure of the narration. In the eastern versions, we find Köroğlu as a legendary character with supernatural features, while in the western narrations, he appears as merely human, albeit noble, and the hero of a folk story. Even the death-bed advice of Köroğlu's father to his son changes in different versions. In the Maraş version, Köroğlu appears as a noble warrior rather than a bandit, who fights for his high ideals and of social justice. We understand this from his father's advice: 
Irz düşmanı olmayacaksın.

Zenginden insaflı olarak alacaksın ve fukaraya dağıtacaksın.

Haksız yere kan dökmeyeceksin.

Zayıf ve hasta olanlara her zaman yardım edeceksin.

Kuvveti senden aşağı olanlarla boy ölçüşmeye kalkmayacaksın. (İçel, 2010: 22)

Be not a man of dishonor.

Receive mercifully from the rich and give to the poor.

Shed not the blood of others unjustly.

Help always the sick and weak.

Strive not with those beneath you. ${ }^{5}$

Finally, it can be summarized that from most Turkish scholars' point of view, Köroğlu was a part of the Celali revolts. However, they have remained open to the possibility that Köroğlu was an epic hero who emerged among the Turcoman (Oghuz) tribes in the wars with Safavids. Another speculation in terms of Köroğlu's origins is that, as Evliya Celebi included in his travel account, there were two Köroğlus in the $16^{\text {th }}$ century, one a troubadour and the other one a warrior. The Turkish scholar Fuad Köprülü, who found the cönks ${ }^{6}$ of the poet Köroğlu, does not give detailed information as to whether these two historical figures were the same person or had any relationship at all. Ekici points out that if we list all these figures as the same person, then Köroğlu becomes a Celali, a military poet and a heroic story character all at the same time. He challenges this idea saying, "yet this can be easily discarded owing to the fact that Köroğlu the poet was a faithful servant of the state, who in his poems praised the soldiers and the pashas and the sultans that took part in the expeditions to Iran, a fact which makes it difficult to relate Köroğlu to Köroğlu the Celali.” (Ekici, 2001: 24)

\section{Yvain in folk tradition: His origins in earlier oral tales}

Although we do not know the exact date on which the $12^{\text {th }}$ century writer Chretien de Troyes wrote the story of Yvain, Kibler in his introduction suggests that this text was written in the second half of the $12^{\text {th }}$ century, and the first manuscripts of Chretien's Arthurian romances are from the $13^{\text {th }}$ century.(Troyes, 1991: 1) Raymond Cormier in his article, "The Love Hero in Early Irish and Old French Literature," discusses the possible connection between the tale of Yvain and two Irish tales from pre-1 $0^{\text {th }}$ century, Serglige Con Culainn, "The Wasting-Sickness of Cui Chulainn," and Tochmarc Emire, "The Wooing of Emer."(Cormier, 1975: 119) According to Bruger, there are more than 17 personages bearing the name Yvain in Arthurian literature, some of whom also have family relationships with each other. (Brugger, 1941: 267-87) For comparison with Köroğlu, the question of whether the character Yvain also origins in the earlier tales of the folk tradition has is the starting point of this section. In the earlier section, it is discussed that there are historical evidence stating that Köroğlu was a historical person. However, we find the poems and stories of the $16^{\text {th }}$ century Köroğlu in texts from earlier centuries as well, making the heroic tales of Köroğlu a part of folk tradition. In the case of Chretien's tale, Yvain is a prince, and we know that this poem was written for a courtly audience. Comparisons are based on affinities and divergences. Although at first it seems that narratives of Köroğlu and Yvain have different origins in folk tradition, the former having a long oral

$5 \quad$ All translations from Turkish to English are my own unless otherwise noted.

Cönk: Manuscripts that were generally written horizontally or vertically by the poet himself or written by someone literate.

RumeliDE Dil ve Edebiyat Arașttrmaları Dergisi Osmanağa Mahallesi, Mürver Ciceği Sokak, No:14/8 Kadıköy - ISTANBUL / TÜRKIYE 34714 e-posta: editor@rumelide.com tel: +90 $5057958124,+902167730616$
Address

RumeliDE Journal of Language and Literature Studies

Osmanağa Mahallesi, Mürver Çiçeği Sokak, No:14/8

Kadıköy - ISTANBUL / TURKEY 34714

e-mail: editor@rumelide.com,

phone: +90 505 7958124, +90 2167730616 
narration tradition, and the latter having been presented only by its author to a courtly audience, Chretien ends his story saying that he also heard it from someone else, concluding as follows: "Thus Chretien brings to a close his romance of the Knight with the Lion. I have not heard any more about it, and you will never hear anything more about it, and you will never hear anything more unless one adds lies to it." (Troyes, 1991: 380)

While the aristocratic setting of the story might correspond to certain aspects of historical reality, there are some supernatural elements in the tale of Yvain. Continuity of folk tradition permits magical or fantastic elements like terrifying beasts, wild herdsmen, a wicked dragon, and two magic rings. Such legendary materials are derived from Celtic sources but are transformed to support the context of the story. As an example, the contextual meaning of the magical ring that Laudine gives to Yvain after their wedding supports the very idea of faithfulness and invulnerability. Cormier supports this idea, saying, "The ring, then, is de-mystified, so to speak, and becomes a symbol of love which further ennobles the noble and protects the courageous." (Cormier, 1975: 132)

Köroğlu, called both a "bandit" and a "warrior against the unjust," criticizes the local rulers harshly in his poems. Although he does not openly criticize the sultan of his time, the figure of the ruler is also not portrayed in a flattering manner. Köroğlu's verses clandestinely criticizing the Sultan composed after he was caught by the soldiers of Bolu Beyi support this argument:

\author{
Şu karşıki yüce dağlar \\ Düşmüşüm namert eline \\ O, mighty mountains before me, \\ I have fallen to a scoundrel
}

\author{
Benim sizde neyim kaldı? \\ Kılıç kalkan yayım kaldı. (Kaftancıŏglu, 1974: 41) \\ What do I owe you? \\ Only my sword, shield, and bow remain.
}

Both narratives function like opponents in a fight arena to support the idea of ideal knighthood and the highest perfection of social and moral values. Yvain is portrayed on one hand as a noble knight performing good deeds and on the other hand as a beast, at the lowest point of humanity. As another example, Yvain and Sir Kay represent another case of opposition in this narrative. While Yvain appears as a mighty knight, being humble and respectful, Kay appears as unruly and rude. Similiarly, we see Köroğlu powerful and humble, and Bolu Beyi as unjust and fearful. There are other adverse/opposite elements such as state authority and injustice in the case of Köroğlu, and in both narratives, city and forest appear as meeting places of opposites.

\section{Lion and horse as companions}

It is not too extreme to say that Yvain's lion and Köroğlu's horse Kırat appear as major characters in both narratives. In fact, some Turkish scholars of Köroğlu, including Boratav, take the next step and identify Kurat as the main character of the plot. In both narratives, we see that these animals symbolize their brave, bold and courageous owners. In Chretien's tale, Yvain is depicted as a lion and praised by the crowd:

Ah, what a valiant warrior! See how he makes his enemies bow before him! How fiercely he attacks them! He strikes among them like a lion, beset and provoked by hunger, among the fallow deer. (Troyes, 1991: 335)

\begin{tabular}{r|l} 
Adres & Address \\
RumeliDE Dil ve Edebiyat Araştırmaları Dergisi & RumeliDE Journal of Language and Literature Studies \\
Osmanağa Mahallesi, Mürver Çiçeği Sokak, No:14/8 & Osmanağa Mahallesi, Mürver Çiçeği Sokak, No:14/8 \\
Kadıköy - İSTANBUL / TÜRKIYYE 34714 & Kadıöy - ISTANBUL / TURKEY 34714 \\
e-posta: editor@rumelide.com & e-mail: editor@rumelide.com, \\
phone: +90 505 7958124, +90 2167730616
\end{tabular}


Interesting enough, instead of seeing the lion as a free wild creature, some scholars suggest that Yvain's lion acts like a dog. Harris' response to this argument is "Chretien always paints from nature: since he has never seen a man with a lion, he describes a man with a dog which has the strength, courage, and nobility of a lion." (page?) The first time that Yvain meets his lion is when the lion is about to be killed by a serpent. Our brave knight rescues the lion without thinking what the lion may do to him afterwards. When the serpent dies, the lion's actions imitate the ceremony of a vassal declaring joy by bowing its head, joining its forepaws, and extending them towards Yvain, who accepts the beast's total submission to himself.(Troyes, 1991: 337) Actually, we see an irony in Chretien's lines in that just before this scene he says that Yvain would not allow anyone to follow or accompany him. However, the opposite happens; after Yvain rescues the lion, it stays with him and never leaves Yvain. Both narrators describe the feelings of these animals in detail, and both animals are depicted as if they understand their masters' language and take actions accordingly. In this sense, both Yvain and Köroğlu have very unique relations with their animal companions. Throughout Yvain's heroic adventures, the lion would save him many times, and this would go to the extreme, in that Yvain would be accused of cravenness without his lion.(Troyes, 1991: 350-51) In this section, we come across a lion who understands that his master is in difficulty although he was commanded not to be involved in the fight that Yvain had with seneschal and his two brothers. Recognizing that Yvain is in need, the lion does not hesitate to come to his aid. In this fight, the lion gets wounded and, although Yvain sustains many injures, the only thing he cares about is his lion:

When my lord Yvain saw his lion wounded, the heart in his breast overflowed with wrath, and rightly so. He struggled to avenge his lion, striking the brothers so hard that they were completely unable to defend themselves against him... And my lord Yvain was far from being uninjured himself, for he had many a wound on his body. Yet he was not as concerned with these as for the suffering of his lion. (Troyes, 1991: 351-52)

The starting point of Köroğlu's story, revenge, is a natural reaction to the unjust situation that Köroğlu's father Yusuf had to face. One day, Bolu Bey, the manor of Bolu, commands his chief stableman, Yusuf, to find a horse for the Sultan. With this gift, his intention is to improve the bad relationship he has with the Sultan. Yusuf takes this order and travels all around Anatolia to find the best horse for his master. He finishes his journey by bringing a weak stallion back to town. To his trained eye, this filly would become a powerful horse if well fed. Bolu Bey sees the weak horse, gets angry and gives a command to his soldiers to blind Yusuf's eyes with a hot iron. After that, Yusuf goes back to his village on the weak horse, and his 15-year-old son, Ali Ruşen, adopts the nickname Köroğlu. The reason for this injustice lies in Kırat, the horse. It is a general characteristic of almost all Turkish epics that they start with a story of the hero's birth. Our Köroğlu story does not have the birth of the hero section, but there are passages of how Kirat becomes a mighty warrior horse and loyal companion of Köroğlu, who regards the horse as an inheritance from his poor father. After listening to his father's advice for raising such a unique horse, he keeps him in a barn one year without seeing any kind of light at all. At the end of the year, Köroğlu puts Kırat in a hole full of mud, and when he draws him back out, Kurat comes out all clean, the only mud on his body being the amount of a walnut shell on his legs.

Kur-at is a combination of two words that literally means gray horse and is believed to be born from the breeding of a river horse (hippo) and a horse and therefore is very fast and powerful.7 In Turkic culture, a horse is regarded as noble and loyal, and the relation between the master and his horse is

Chodzko, on page 29 of his book, translates Kirat as "chestnut horse," but since these two words, krr and at, are of Turkic origin, the first word meaning "gray" and the second "horse," Chodzko's translation is misleading.

Adres $\mid$ Address

RumeliDE Dil ve Edebiyat Araşttrmaları Dergisi $\quad$ RumeliDE Journal of Language and Literature Studies Osmanağa Mahallesi, Mürver Çiçeği Sokak, No:14/8 Osmană̆a Mahallesi, Mürver Çiçeği Sokak, No:14/8

Kadıköy - ISTANBUL / TÜRKIYE 34714 Kadıköy - ISTANBUL / TURKEY 34714 e-posta: editor@rumelide.com

e-mail: editor@rumelide.com

tel: +90 505 7958124, +90 2167730616 phone: +90 505 7958124, +90 2167730616 
The role of performance in constructing identity in the East and the West: comparison of the narratives of Köroğlu and the Knight with the Lion (Yvain) / Z. Elbasan Bozdoğan (pp. 708-719)

unique. Boratav sees Kırat as the main character of the Köroğlu narrative, indicating that in the eyes of his master, Kurat bears the first place in importance. (Boratav, 1984: 68) A good example of this can be found in the lines in which Köroğlu called his horse "My eye! My soul!"

\author{
Kır Atın elinden babam can mı kurtulur? \\ Canım Kır At gözüm Kır At! \\ Her yanında çifte kanat, \\ Whose soul is safe from Kirat, Father? \\ Kurat, my soul; Kurat, my eyes! \\ His legs are twin pairs of wings,
}

\author{
Elma gözlü Kır Atım benim! \\ Sana olsun murat, \\ Uçar gider, ha gider, ha gider. (Boratav, 1984: 67)
}

Apple-eyed Kurat of mine!

Wishes are granted!

On which he flies here and flies there.

This passage, in which Kurat has been stolen by Bolu Beyi, is related to our argument about the close relation between Köroğlu and his horse. Köroğlu does not take any action in his story without composing poems. For the stolen Kurat, he recites:

\author{
Hükümdarım düştüm bir ah u zara \\ Bütün varlığını döksen pazara \\ Kurat'ı almaktır senın harayın \\ Meydana getirsen köşk ü sarayın \\ My ruler, I am in moan and lamentation. \\ Even if you put all your wealth out on a market, \\ Your intention is to take Kirat \\ Even if you construct a mansion or a palace
}

\author{
Korkarım sonunda gelirsin dara \\ Kırat'ın giderken yelini değmez \\ Elçi gönderüben vermişsin rayın \\ Kıratın bir tane kılını değmez (Öztelli, 1962: 166) \\ I am afraid, you will be in a difficulty: \\ None of them reaches the wind of Kırat, walking.
}

You already made your decision by sending a Messenger

None of them reaches the hair of Kurat.

Meanwhile Bolu Bey's vassals have had a hard time to ease Kirat, who is left without dear master, Köroğlu, and becomes very sad because of this seperation. In fact, Kirat is like a talisman/charm/amulet for Köroğlu, who makes a plan, disguises himself as one of the stablemen of Bolu Beyi, and finds his horse. After numerous adventures, Kurat gets old and dies. In the Azeri version, Kurat is killed by Behram and Almas Khans by cutting the veins of all four legs. Köroğlu laments after his horse by reciting poems and dies soon after. There are various poems and songs regarding this episode, but the Azeri version has the most eloborate episode of this event. Köroğlu clasps his head with both hands and sings his song before he is murdered by Almas Khan and Bahram Khan:

Villains, come nearer! You have killed my Kurat, there is my bosom, strike! I shall not defend myself any longer, take my life also. Without Kırat I am useless in this world. (Chodzko, 1842: 341)

\section{The similarities between female characters in the narratives}

In both narratives we see a common theme of the proper treatment of women as a part of knightly identity. Both heroes have legendary actions, and they are both praised by the women around them. The only exception in Yvain's story is Laudine, "whose ire serves as the central dramatic tension of the work." (Han, 2010) Actually, the courtly love between Yvain and Laudine serves the purpose of an ideal love which at the same time strengthens the characteristic features of an ideal knight. Burns indicates that the emergence of courtly love is interrelated with the emergence of a protean process of

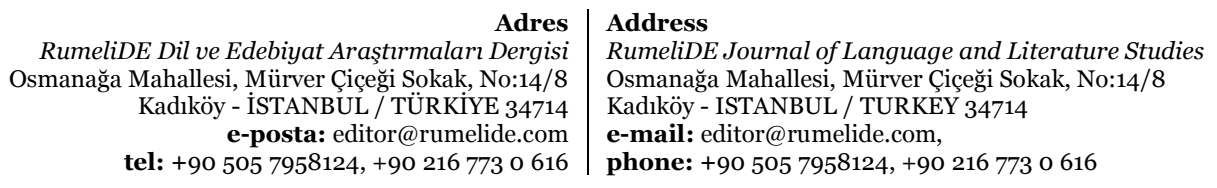


social interaction. Burns remarks: "Courtly love, when taken as the full range of amorous scenarios staged between elite heterosexual couples in a court setting, offers models for love relations that disrupt the binary and exclusive categories of male and female and masculine and feminine used typically to structure the Western romantic love story." (Burns, 2001: 48-9) When we look at Yvain's interactions with Lunete the damsel, he is being praised constantly and being assisted by her because Lunete thinks he is a courageous man: "For I will do everything in my power to assist you. A man is not brave if he is too easily frightened; but since you've not been too frightened, I believe you are a brave man. (Troyes, 1991: 307)

Lunete brings some food and beverages to Yvain to rejuvenate him, and she also lends him a magical ring to protect him from harm. This can be regarded as a gender role reversal as Yvain is rescued by a woman:" It will be your shield and hauberk; in truth, I have never before lent or entrusted it to any knight, but out of love I give it to you." (Troyes, 1991: 328) After listening to Lunete's story of being under accusation of betraying her lady later in the tale, Yvain decides to become Lunete's champion as to show his friendship and courtesy for Lunete. Actually, Lunete is different from other female characters in the story as she acts independently and is not manipulated by other people. Another example of Yvain's interaction with females can be seen when Yvain meets the younger sister of a woman who refuses to share her inheritance. In order to resolve the problem between the elder sister and younger sister Yvain strives to find a resolution to the situation that Gawain's thoughtless promise worsened. The younger sister remarks that she would spend all her life seeking for the Knight with the Lion who devoted himself to helping women in need of assistance. (Troyes, 1991: 355) This is the new name that Yvain takes as a way of earning back the love of his wife, to whom he broke his promise while seeking adventure with Gawain. This transformation in name is reflected in his many heroic acts in defense of women, and he wins back his wife's love at the end of the tale.

In representation of the heroes, the common similarity is the courtesy that an ideal hero should have, and women in both narratives play great role to highlight this feature. In the case of Köroğlu, his heroic deeds are praised by the women although they don't find him physically attractive. In the Istanbul branch of the narrative, his physical appearance is depicted as "eni uzunundan artık", meaning he is as tall as he is wide. One of his lovers, Nigar Hanım says: "Bu karalığınla, bu çirkinliğinle bir de yiğit olmasaydın senin halin ne olurdu?" (Boratav, 1984: 73) Although in most of the versions he is not a member of nobility, Köroğlu almost always has love affairs with noble women. As Chodzko says, "He is an aristocrat only in love, and chooses his sweethearts amongst the daughters of princes and men of rank." (Chodźko, 1842: 8) His heroic story bears the features of a romance as he has many love stories in his adventures. He remarks on those in his improvisations:

(i) Kimisi pınar başında

Kimisi yolun dişında

$\mathrm{Al}$ giyen on beş yaşında

İlle mavili mavili

(iii)Kimisi odun devşirir

Kimi kahvesin pişirir

$\mathrm{Al}$ giyen aklım şaşırır

İlle mavili mavili
(ii)Kimisi dağlarda gezer

Kimisi incisin dizer

Al giyen bağrımı ezer

İlle mavili mavili

(iv)Köroğlu'm der ki n’olcak

Takdir yerini bulacak

Mavilim kaldı alacak

İlle mavili mavili (Köprülü, 1962: 94-95)
Adres
RumeliDE Dil ve Edebiyat Araştırmaları Dergisi
smanağa Mahallesi, Mürver Çiçeği Sokak, No:14/8
Kadıköy - İSTANBUL / TÜRKIYE 34714
e-posta: editor@rumelide.com
tel: +90 505 7958124, +90 2167730616

isi

Address

RumeliDE Journal of Language and Literature Studies

Osmanağa Mahallesi, Mürver Çiçeği Sokak, No:14/8

Kadıköy - ISTANBUL / TURKEY 34714

e-mail: editor@rumelide.com,

phone: +90 505 7958124, +90 2167730616 
The role of performance in constructing identity in the East and the West: comparison of the narratives of Köroğlu and the Knight with the Lion (Yvain) / Z. Elbasan Bozdoğan (pp. 708-719)

(i) Some of them are next to a fountain

The one who wears scarlet (color) is in her 15

(ii) Some wander in mountains

My chest is torn by the scarlet one

(iii) Some collect woods

My mind is puzzled by the scarlet one.

(iv) I, Köroğlu, ask what will happen

The only (woman) left to marry is the blue one
Some of them are next to a path (way)

Especially the blue one, the blue one

Some sets pearls

Especially the blue one, the blue one

Some cook coffee

Especially the blue one, the blue one

The will of God will find its place

Especially the blue one, the blue one.

After having various love affairs in different lands, Köroğlu ends up marrying Nigar Hanım. This figure of Nigar Hanım can be regarded as a combination of Lunete and Laudine. She does not ask for more, respects her husband, although they live apart throughout the story because of Köroğlu's adventures in other places. We see another gender role reversal in this case as well. In a specific instance, she saves her husband from death. One day, Bolu Beyi kidnaps Köroğlu and puts him in a jail. Nigar Hanım waits for his husband for forty days and after that she calls out Köroğlu's brave men and tells them that Köroğlu might be in a difficult situation and goes with them to the castle of Bolu Bey to save her beloved husband. All the female characters including Nigar Hanım somehow appears as helping characters being invisible in the narratives. We do not know about their feelings at all, and their only function is to aid the idealization process of Köroğlu. When we compare Nigar Hanım to Laudine, we see the former more obedient in terms of fulfilling the role of a wife than the latter. We do not see Nigar Hanım taking any action against the seperations that she goes through with Köroğlu as Laudine does. Even though her servant Lunete tries to calm her lady by praising Yvain, Laudine does eventually listen to Lunete in both accepting marriage to Yvain and forgiving him at the end

\section{Conclusion}

These two texts provide a tradition of oral transmission as they are not purely created literary products. In the case of Köroğlu, it is natural to observe transitions from the simpler intellectual life to the more complex expressions of higher cultures throughout the centuries. In Yvain, Chretien says that this story is not his own production as heard it from someone else. So, there might be some changes in characters, maybe some adding of subordinate characters to contrast or support the main character.

Yvain and Köroğlu exceed the boundaries of the region from which they emerged by reflecting the ideals that are similar to those of the common people. The ideal of courtesy is the main way of representing their way of life. Their representations of ideal knighthood - courage, brave, respectful, fighting for the just- can be adopted by any society. Both characters' origins do not root from the narratives we discussed above; therefore, they are recreated / shaped for the audience by their narrators.

One of the signs of an ideal knight is nobility and Yvain is already coming from a noble family. The second sign which is the only way to prove the ideal knighthood in the case of Köroğlu is the achievement of the knightly deed and the ability to fight. Heraldic symbols that Yvain and Köroğlu take also introduce the issue of adopting a new identity. Their companions, lion and horse, can be viewed as their new heraldic symbols. These two animals symbolize the nobility and power in their cultures where the stories emerged. However, both Yvain and Köroğlu do not let their new identities redefine

\begin{tabular}{|c|c|}
\hline \\
\hline & Ad \\
\hline ımeliDE Dil ve Edebiyat Araştırmaları Dergisi & RumeliDE Journal of Language and Literature Studies \\
\hline Osmanağa Mahallesi, Mürver Çiçeği Sokak, No:14/8 & Osmanağa Mahallesi, Mürver Çiçeği Sokak, No:14/8 \\
\hline Kadıköy - İSTANBUL / TÜRKIYYE 34714 & Kadıköy - ISTANBUL / TURKEY 34714 \\
\hline $\begin{array}{r}\text { e-posta: editor@rumelide.com } \\
\text { tel: }+905057958124,+902167730616\end{array}$ & $\begin{array}{l}\text { e-mail: editor@rumelide.com, } \\
\text { phone: +90 505 7958124, +90 } 2167730616\end{array}$ \\
\hline
\end{tabular}


themselves. In fact, they see themselves interrelated with their animals and they grow in their fame together.

The role of female characters is important in helping Köroğlu and Yvain adopt new identities as well. As Kibler and Carroll remark, "Yvain neglects his bride (amors) in the pursuit of glory (armes)" (Troyes, 1991: 9) The perfect balance in the stories of Köroğlu and Yvain, not a perfect lover or a perfect knight, makes the stories more human to the reader. Yvain becomes an unfaithful husband and bad knight by breaking his promise to Laudine. The fact that Köroğlu is saved from danger by a woman shows both the gender role reversal and redefining of his identity. Köroğlu in his fight with Bolu Bey hides himself in difficult situations rather than risking his life. In the loss of knighthood episodes, where Yvain stays in the forest and lives like an animal and Köroğlu becomes powerless after his horse Kirat is kidnapped, symbolize a new identity adaptation. In both narratives, although they do not perform as major characters of the plot, women play active roles of saving the heroes from death, wounding and protecting them. The question of equality of genders may be intact but since the act of life saving is performed both ways by different gender characters (Yvain-Lunete, Köroğlu-Nigar Hanım), it would not be too extreme to say that both narratives reveal the equality of genders.

\section{Bibliography}

Boratav, P. N. (1984). Köroğlu Destanı. İstanbul : Adam.

Brugger, E. (1941). "Yvain and His Lion." Modern Philology 38(3): 267-287.

Burns, J. (2001). "Courtly Love: Who Needs It? Recent Feminist Work in the Medieval French Tradition." Signs 27(1): 23-57.

Chodzko, A. (1842). Specimens of the popular poetry of Persia, as found in the adventures and improvisations of Kurroglou, the bandit-minstrel of northern Persia and in the songs of the people inhabiting the shores of the Caspian Sea. London, Harrison and Co.

Combellack, C. R. B. "Yvain's Guilt." Studies in Philology 68(1): 10-25.

Cormier, R. J. (1975). "Cú Chulainn and Yvain: The Love Hero in Early Irish and Old French Literature." Studies in Philology 72(2): 115-139.

Çevik, M. (1984) Seyahatname. İstanbul, Üçdal Neşriyyat: v.5.

Ekici, M. (2001). Popularization of Köroğlu. 5th Annual Cultural Seminar: New Cultural Perspectives in the New Millenium. İzmir, Ege University.

Han, Dongdong (2010). The Legend of Yvain, Camelot Project. http://d.lib.rochester.edu/camelot/text/han-the-legend-of-yvain

Harris, J. (1949). "The Rôle of the Lion in Chrétien de Troyes' Yvain." Modern Language Association 64 (5).

İçel, H. (2010). Köroğlu'nun Bolu Beyi Kolu Üzerine Bir İnceleme. Konya : Kömen.

Kaftancıoğlu, Ü. (1974). Köroğlu Kolları. İstanbul, Büyük Yayın.

Köprülü, F. (1962). Türk Saz Şairleri. Ankara, Milli Kültür Yayınları.

Olrik, A. (1992). Principles for Oral Narrative Research. Bloomington, Indiana University Press.

Öztelli, C. (1962). Köroğlu ve Dadaloğlu. Istanbul : Ekin.

Sumer, F. and N. Albayrak (1988). Köroğlu. Islam. Istanbul, ISAM. 26: 268-270.

Troyes, C. d. (1991). Arthurian Romances, Trans. Kibler, Carleton: Penguin Classics.

Wilks, J. M. (2001). "The Persianization of Köroğlu: Banditry and Royalty in Three Versions of the Köroğlu 'Destan'”. Asian Folklore Studies 6o(2): 305-318.

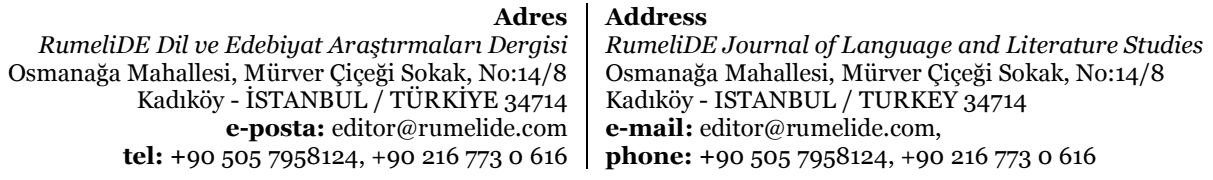

tel: +90 505 7958124, +90 2167730616 